\title{
Hubungan Pendidikan, Pekerjaan, Sikap dan Pengetahuan Ibu dengan Ketepatan Waktu Pemberian Imunisasi BCG Pada Bayi
}

\author{
Leli Oktalina ${ }^{1}$, Murdiningsih ${ }^{2}$, Sri Handayani ${ }^{3}$ \\ Universitas Kader Bangsa Palembang ${ }^{1,2,3}$
}

\author{
Informasi Artikel : \\ Diterima : 30 Oktober 2021 \\ Direvisi : 02 November 2021 \\ Disetujui : 20 Desember 2021 \\ Diterbitkan : 30 Desember 2021 \\ *Korespondensi Penulis : \\ leli.oktalina88@gmail.com ${ }^{1}$, \\ murdi.ningsih1957@gmail.com², \\ handa.yani8108@gmail.com ${ }^{3}$
}

\begin{abstract}
A B S T R A K
Salah satu target keberhasilan program imunisasi adalah tercapainya Universal Child Immunization (UCI) yang merupakan cakupan imunisasi dasar lengkap bayi secara merata pada bayi di $100 \%$ desa/kelurahan. Adapun faktor yang berhubungan dengan pemberian imunisasi dasar lengkap pada bayi antara lain pengetahuan, pendidikan, pekerjaan, sikap, pelayanan imunisasi, motivasi dan informasi imunisasi. Tujuan penelitian ini untuk mengetahui hubungan Pendidikan, Pekerjaan, Sikap dan Pengetahuan Ibu dengan ketepatan waktu pemberian imunisasi BCG pada bayi di wilayah kerja Puskemas Taman Bacaan Kota Palembang tahun 2021. Metode penelitian menggunakan survey analitik dengan pendekatan cross sectional. Populasi penelitian ini adalah semua ibu yang membawa bayinya pada saat jadwal pelayanan imunisasi di Posyandu wilayah kerja Puskesmas Taman Bacaan Kota Palembang bulan Juli dan Agustus Tahun 2021. Pada penelitian ini, sampel diambil menggunakan teknik total sampling, yang mana teknik Accidental Sampling yaitu sejumlah 87 anak. Instrumen penelitian menggunakan kuesioner. Analisa data menggunakan Analisa univariat dan analisa bivariat dengan menggunakan uji chi square. Hasil penelitian ada hubungan antara Pendidikan $(p$ value $=0.000)$, pekerjaan $(p$ value $=0.000)$, sikap $(p$ value $=0,000)$, dan pengetahuan ( $p$ value $=0,000)$ dengan ketepatan waktu pemberian imunisasi BCG pada bayi di wilayah kerja Puskesmas Taman Bacaan Kota Palembang Tahun 2021. Diharapkan dapat lebih meningkatkan penyuluhan tentang jadwal pemberian imunisasi dasar lengkap secara tepat waktu dan memberikan konseling secara langsung kepada masyarakat agar pengetahuan warga setempat dapat bertambah.
\end{abstract}

Kata Kunci : Imunisasi BCG, Pekerjaan, Pendidikan, Pengetahuan, Sikap

\begin{abstract}
One of the targets for the success of the immunization program is the achievement of the Universal Child Immunization (UCI), which is a complete coverage of basic infant immunization that is evenly distributed among infants in $100 \%$ of villages. The factors related to the provision of complete basic immunization to infants include knowledge, education, occupation, attitudes, immunization services, motivation and immunization information. The objective of this study was to disclose the relationship of Mother's Education, Occupation, Attitude and Knowledge towards the timeliness of administering BCG immunization to infant in the working area of the Taman Bacaan Public Health Center in Palembang City in 2021. The method of the study was an analytical survey with a cross sectional approach. The population of this study was all mothers taking their babies during the immunization
\end{abstract}


service schedule at the integrated Healthcare Center for under five toodlers in the working area of the Taman Bacaan Public Health Center in Palembang in July and Agustus 2021. In This study, The sample was taken using a total sampling technique, in which The Accidental Sampling technique was a number of 87 children. The instrument of the study was a questionnaire. The data were analyzed using univariate analysis and bivariate analysis using chi square test. The result of the study showed that there was a relationship between education ( $p$ value $=0,000$ ), occupation ( $p$ value $=0,000)$, attitudes ( $p$ value $=0,000)$ and knowledge ( $p$ value $=0,000)$ and the timeliness of administering $B C G$ Imunnization to infants in the working area of Taman Bacaan Public Health Centerin Palembang City in 2021. It is expected that the health workers further increase counseling about the schedule for administering complete basic immunizations in a timely manner and provide direct conseling to the community so that local resiodents' knowledge can increase.

Keywords : BCG Immunization, Occupation, Education, Knowledge, Attitude

\section{PENDAHULUAN}

Salah satu target keberhasilan program imunisasi adalah tercapainya Universal Child Immunization (UCI) yang merupakan cakupan imunisasi dasar lengkap bayi secara merata pada bayi di 100\% desa/kelurahan. Sesuai dengan Keputusan Menkes RI dan Riset Kesehatan Dasar (Riskesdas) tahun 2019 menyatakan UCI adalah suatu keadaan tercapainya imunisasi dasar secara lengkap pada semua bayi (anak dibawah umur 1 tahun). Pencapaian UCI pada dasarnya merupakan proyeksi terhadap cakupan atas imunisasi secara lengkap pada kelompok sasaran bayi. Bila cakupan UCI dikaitkan dengan batasan suatu wilayah tertentu, berarti dalam wilayah tersebut juga tergambarkan besarnya tingkat kekebalan masyarakat (herd immunity) terhadap penularan Penyakit Menular yang Dapat Dicegah Dengan Imunisasi (PD3I). Persentase desa yang mencapai UCI di Provinsi Sumatera Selatan pada tahun 2019 sebesar 93,7\%. Jika dibandingkan dengan indikator RPJMN/Renstra 2019-2023 dimana target tahun 2019 adalah sebesar 95\%, maka angka ini berarti belum mencapai target. Terdapat 2-3 juta kematian anak di dunia setiap tahunnya dapat dicegah dengan pemberian imunisasi, namun sebanyak 22,6 juta anak di seluruh 3 dunia tidak terjangkau imunisasi rutin. Di Indonesia lebih dari 13\% anak usia 0-11 bulan belum mendapatkan imunisasi dasar secara lengkap. (Profil Dinas Kesehatan Provinsi Sumatera Selatan, 2020).

Data Riskesdas 2019 menunjukkan bahwa $32,1 \%$ bayi di Indonesia tidak mendapatkan imunisasi dasar lengkap dan $8,7 \%$ bayi tidak melakukan imunisasi, sedangkan di Sumatera Selatan yang tidak mendapatkan imunisasi dasar lengkap sebesar 33,9 \% dan bayi yang tidak melakukan imunisasi sebesar $14 \%$.

Memenuhi jadwal imunisasi anak sangat penting untuk mencegah penyakit serius dikemudian hari. Terutama beberapa imunisasi dasar yang direkomendasikan oleh Kementerian Kesehatan RI dan Ikatan Dokter Anak Indonesia (IDAI). Alasan untuk tidak memberikan imunisasi pada anak juga sebenarnya tidak ada, karena vaksinnya bisa diperoleh secara gratis di pusat layanan kesehatan milik pemerintah. (Kemenkes RI, 2020). 
Berbagai alasan ibu tidak membawa balitanya ke posyandu, antara lain karena letaknya yang jauh, tidak ada kegiatan posyandu, serta layanan tidak lengkap walaupun sudah diberikan fasilitas gratis oleh pemerintah. Hal tersebut dikarenakan berbagai alasan seperti pengetahuan ibu yang kurang tentang imunisasi dan rendahnya kesadaran ibu membawa anaknya ke posyandu atau puskesmas untuk mendapatkan imunisasi yang lengkap karena takut anaknya sakit, dan ada pula yang merasa bahwa imunisasi tidak diperlukan untuk bayinya, kurang informasi/penjelasan dari petugas kesehatan tentang manfaat imunisasi serta hambatan lainnya. Faktor yang berhubungan dengan pemberian imunisasi dasar lengkap pada bayi meliputi beberapa hal, salah satunya yang menyatakan bahwa faktor yang berhubungan dengan pemberian imunisasi dasar lengkap pada bayi antara lain pengetahuan, pendidikan, pekerjaan orang tua, sikap, pelayanan imunisasi, motivasi dan informasi imunisasi. (Triana Vivi, 2018)

Berdasarkan penelitian Albertina, dkk (2019) tentang faktor-faktor yang berhubungan dengan Ketepatan waktu pemberian imunisasi BCG. Hasil penelitian menunjukan bahwa faktor yang berhubungan bermakna dengan ketepatan waktu dini pemberian imunisasi yaitu pendidikan $(p=0,001)$, pengetahuan $(p=0,043)$, sikap $(p=0,032)$, dan pekerjaan $(p=0,012)$. Hasil penelitian menurut Fitriani Sahid (2018) menunjukkan bahwa ada hubungan yang signifikan antara pekerjaan dengan ketepatan waktu pemberian Imunisasi BCG pada Bayi di wilayah kerja Puskesmas Maligano kabupaten Muna yang ditandai dengan nilai $\mathrm{p}$ $=0,000<\alpha=0,05$ dengan X2 hitung = 23,975 dan nilai $\mathrm{p}=0,022<\alpha=0,05$ dengan $\mathrm{X} 2$ hitung $=5,259$. Penelitian Albertina, dkk
(2019) tentang faktor-faktor yang berhubungan dengan Ketepatan waktu pemberian imunisasi BCG. Hasil penelitian menunjukan bahwa faktor yang berhubungan bermakna dengan ketepatan waktu dini pemberian imunisasi yaitu pendidikan $(p=0,001)$, pengetahuan $(p=0,043)$, sikap $(\mathrm{p}=0,032)$, dan pekerjaan $(\mathrm{p}=0,012)$. Penelitian menurut Yulinda (2018) menyatakan bahwa ada hubungan Pengetahuan ibu dengan Pemberian Imunisasi BCG pada Bayi Usia 0-3 Bulan di Wilayah Kerja Puskesmas Bireum Bayeun Kecamatan Bireum Bayeun Kabupaten Aceh Timur Tahun 2018.

Tujuan dari penelitian ini adalah untuk mengetahui hubungan pendidikan, pekerjaan, sikap dan pengetahuan ibu dengan ketepatan waktu imunisasi BCG pada bayi di Puskesmas Taman Bacaan Kota Palembang.

\section{METODE PENELITIAN}

Jenis penelitian yang dilakukan adalah penelitian kuantitatif, menggunakan desain penelitian analitik dengan cara pendekatan Cross Sectional dimana variabel independen (pendidikan, pekerjaan, sikap dan penegetahuan) dan variabel dependen (ketepatan waktu imunisasi BCG). Penelitian ini dilakukan di Posyandu balita yang ada di wilayah Puskesmas Taman Bacaan Jl.KH.Azhari Lorong Taman Bacaan Kelurahan Tangga Takat Kecamatan Seberang Ulu II Kota Palembang. Penelitian ini dilaksanakan pada bulan Juli sampai dengan Agustus 2021.

Populasi penelitian ini adalah semua ibu yang membawa bayinya pada saat jadwal pelayanan imunisasi di Posyandu balita wilayah kerja Puskesmas Taman Bacaan Kota Palembang bulan Juli dan Agustus Tahun 2021 yaitu sebanyak 87 anak. Pada penelitian ini, sampel diambil menggunakan 
teknik total sampling, yang mana teknik Accidental Sampling yaitu ibu yang membawa bayinya dan ingin memberikan imunisasi BCG pada bayinya pada saat pelayanan Imunisasi sejumlah 87 anak. Data primer pada penelitian yaitu data yang diambil langsung dengan melakukan wawancara langsung kepada responden yang berkunjung ke posyandu yang ada di wilayah Puskesmas Taman Bacaan Kota Palembang dengan menggunakan kuesioner sebagai alat bantu pengumpulan data.

Analisis data menggunakan analsis univariat dan analisis bivariat, Analisis univariat digunakan untuk memperoleh gambaran distribusi frekuensi dan presentase dari semua variabel penelitian, yaitu pendidikan, pekerjaan, sikap dan pengetahuan (variabel independen), dan ketepatan pemberian imunisasi BCG pada bayi (variabel dependen). Sedangkan analisis bivariate digunakan untuk mengetahui hubungan antara variabel independen dengan variabel dependen menggunakan uji statistik Chi Square. Batas kemaknaan yang digunakan dalam penelitian ini adalah $\alpha=$ 0,05. Pengambilan keputusan statistik dengan ketentuan bila $p$ value $\leq$ nilai $\alpha(0,05)$, maka ada hubungan antara variabel independen dengan variabel dependen. Bila $p$ value $>$ nilai $\alpha(0,05)$, maka tidak ada hubungan antara variabel independen dengan variabel dependen.

\section{HASIL PENELITIAN}

Hasil penelitian disajikan dalam bentuk Analisis univariat dan bivariat. Analisis univariat dalam penelitian ini akan menggambarkan distribusi frekuensi dari seluruh variable yaitu ketepatan waktu pemberian imunisasi BCG, pendidikan, pekerjaan, sikap dan penetahuan.

a. Analisis Univariat

Tabel 1 Hasil Univariat
Variabel

Frekuensi

Persentase

Ketepatan

Imunisasi BCG

\begin{tabular}{lll}
\hline Tidak tepat & 46 & $52.9 \%$ \\
\hline Tepat & 41 & $47.1 \%$ \\
\hline
\end{tabular}

\begin{tabular}{lll}
\hline Pendidikan & & \\
\hline Rendah & 50 & $57.5 \%$ \\
\hline Tinggi & 37 & $42.5 \%$ \\
\hline
\end{tabular}

Pekerjaan

Tidak bekerja

Bekerja

56

$64.4 \%$

$35.6 \%$

Sikap

Negatif

31

Positif

46

$52.9 \%$

41

$35.6 \%$

Pengetahuan

Kurang baik

Baik

45

$51.7 \%$

42

$48.3 \%$

Berdasarkan tabel 1 dari 87 responden, yang tidak tepat dalam pemberian imunisasi pada bayinya, yaitu sejumlah 46 responden (52,9\%) lebih banyak dari responden yang tepat yaitu sebanyak 41 responden $(47,1 \%)$. Responden yang pendidikannya rendah yaitu sebanyak 50 responden $(57,5 \%)$ lebih banyak dari responden yang pendidikannya tinggi yaitu sebanyak 37 responden (42,5\%). Responden yang tidak bekerja sebanyak 56 responden $(64,4 \%)$ lebih banyak dari responden yang bekerja yaitu sebanyak 31 responden $(35,6 \%)$. Responden yang tidak mendukung sebanyak 46 responden $(52,9 \%)$ lebih banyak daripada responden yang mendukung yaitu sebanyak 41 responden $(47,1 \%)$. Responden yang pengetahuannya kurang baik sebanyak 45 responden $(51,7 \%)$ lebih banyak dari responden yang pengetahuannya baik yaitu sebanyak 42 responden $(48,3 \%)$.

\section{b. Analisis Bivariat}

Analisa bivariat digunakan untuk mengetahui hubungan antara variabel independen (pendidikan, pekerjaan, sikap dan pengetahuan) dengan variabel dependen 
(ketepatan waktu pemberian imunisasi $\mathrm{BCG}$ pada bayi)

Uji statistik yang digunakan adalah uji Chi-Square dengan program SPSS versi 23.0 dengan menggunakan batas kemaknaan atau nilai $\alpha=0,05$ dan $\mathrm{df}=1$, jika $p$ value $\leq 0,05$ bearti ada hubungan yang bermakna antara variabel independen dengan variabel dependen dan jika $p$ value $>0,05$ bearti tidak ada hubungan antara variabel independen dengan variabel dependen.

Tabel 2 Hasil Bivariat Hubungan Pendidikan, Pekerjaan, Sikap dan Pengetahuan dengan ketepatan waktu pemberian imunisasi BCG Pada Bayi

\begin{tabular}{|c|c|c|c|c|c|c|c|c|c|}
\hline \multirow[t]{3}{*}{ Variabel } & \multirow{3}{*}{$\begin{array}{l}\text { Hasil } \\
\text { ukur }\end{array}$} & \multicolumn{4}{|c|}{ Ketepatan Imunisasi BCG } & \multirow{2}{*}{\multicolumn{2}{|c|}{ Total }} & \multirow{3}{*}{$\begin{array}{c}\text { P- } \\
\text { Value }\end{array}$} & \multirow[t]{3}{*}{ OR $(95 \%$ CI $)$} \\
\hline & & \multicolumn{2}{|c|}{ Tidak tepat } & \multicolumn{2}{|c|}{ Tepat } & & & & \\
\hline & & Jumlah & $\%$ & Jumlah & $\%$ & Jumlah & $\%$ & & \\
\hline \multirow[t]{2}{*}{ Pendidikan } & Rendah & 37 & 74,0 & 13 & 26,0 & 50 & 100 & \multirow[t]{2}{*}{0,000} & 8.855 \\
\hline & Tinggi & 9 & 24,3 & 28 & 75,7 & 37 & 100 & & $(3,318-23,628)$ \\
\hline \multirow[t]{3}{*}{ Pekerjaan } & Tidak & 20 & 35,7 & 36 & 64,3 & 56 & 100 & \multirow[t]{3}{*}{0,000} & 0,107 \\
\hline & Bekerja & & & & & & & & $(0,035-0,322)$ \\
\hline & Bekerja & 26 & 83,9 & 5 & 16,1 & 31 & 100 & & \\
\hline \multirow[t]{2}{*}{ Sikap } & Negatif & 37 & 80,4 & 9 & 19,6 & 46 & 100 & \multirow[t]{2}{*}{0,000} & 43,313 \\
\hline & Positif & 9 & 22,0 & 32 & 78,0 & 41 & 100 & & \\
\hline \multirow[t]{2}{*}{ Pengetahuan } & $\begin{array}{l}\text { Kurang } \\
\text { baik }\end{array}$ & 37 & 80,4 & 8 & 17,8 & 45 & 100 & \multirow[t]{2}{*}{0,000} & $\begin{array}{c}16,958 \\
(5,865-49,032)\end{array}$ \\
\hline & Baik & 9 & 22,0 & 33 & 78,6 & 42 & 100 & & \\
\hline
\end{tabular}

Hasil analisis hubungan antara pendidikan dengan ketepatan pemberian imunisasi BCG pada bayi didapatkan hasil dari 50 responden yang pendidikannya rendah yaitu sebanyak 37 responden $(74,0 \%)$ yang tidak tepat waktu dalam memberikan imunisasi BCG pada bayinya dan sebanyak 13 responden $(26,0 \%)$ yang tepat waktu dalam memberikan imunisasi BCG pada bayinya.

Dari uji statistik Chi-Square pada tingkat kemaknaan $\alpha=0,05$ diperoleh nilai $p$ value $=0,000$ yang berarti ada hubungan Pendidikan dengan ketepatan waktu pemberian imunisasi BCG sehingga hipotesis yang menyatakan bahwa ada hubungan pendidikan ibu dengan ketepatan waktu pemberian Imunisasi BCG pada bayi terbukti secara statistik.

Hasil Odds Ratio diperoleh nilai 8,855 yang berarti bahwa responden yang pendidikannya tinggi berpeluang 8,855 kali lebih besar ketepatan waktunya dalam memberikan imunisasi BCG pada bayinya dibandingkan dengan responden yang berpendidikan rendah.

Hasil analisis hubungan antara pekerjaan dengan ketepatan pemberian imunisasi BCG pada bayi didapatkan hasil dari 56 responden yang tidak bekerja yaitu sebanyak 20 responden $(35,7 \%)$ yang tidak tepat waktu dalam memberikan imunisasi BCG pada bayinya dan sebanyak 36 responden $(64,3 \%)$ yang tepat waktu dalam memberikan imunisasi BCG pada bayinya.

Dari uji statistik Chi-Square pada tingkat kemaknaan $\alpha=0,05$ diperoleh nilai $p$ value $=0,000$ yang berarti ada hubungan pekerjaan ibu dengan ketepatan waktu pemberian imunisasi BCG sehingga hipotesis yang menyatakan bahwa ada hubungan pekerjaan ibu dengan ketepatan waktu pemberian Imunisasi BCG pada bayi terbukti secara statistik. 
Hasil Odds Ratio diperoleh nilai 0,107 yang berarti bahwa responden yang tidak bekerja berpeluang 0,107 kali lebih besar ketepatan waktunya dalam memberikan imunisasi BCG pada bayinya dibandingkan dengan responden yang bekerja.

Hasil analisis hubungan antara sikap dengan ketepatan pemberian imunisasi BCG pada bayi didapatkan hasil dari 46 responden yang tidak mendukung yaitu sebanyak 37 responden $(80,4 \%)$ yang tidak tepat waktu dalam memberikan imunisasi BCG pada bayinya dan sebanyak 9 responden $(19,6 \%)$ yang tepat waktu dalam memberikan imunisasi BCG pada bayinya.

Dari uji statistik Chi-Square pada tingkat kemaknaan $\alpha=0,05$ diperoleh nilai $p$ value $=0,000$ yang berarti ada hubungan sikap ibu dengan ketepatan waktu pemberian imunisasi BCG sehingga hipotesis yang menyatakan bahwa ada hubungan sikap ibu dengan ketepatan waktu pemberian Imunisasi BCG pada bayi terbukti secara statistik.

Hasil Odds Ratio diperoleh nilai 43,313 yang berarti bahwa responden yang mendukung berpeluang 43,313 kali lebih besar ketepatan waktunya dalam memberikan imunisasi BCG pada bayinya dibandingkan dengan responden yang tidak mendukung.

Hasil analisis hubungan antara pengetahuan dengan ketepatan pemberian imunisasi BCG pada bayi didapatkan hasil dari 45 responden yang pengetahuannya kurang baik yaitu sebanyak 37 responden $(82,2 \%)$ yang tidak tepat waktu dalam memberikan imunisasi BCG pada bayinya dan sebanyak 8 responden $(17,8 \%)$ yang tepat waktu dalam memberikan imunisasi BCG pada bayinya.

Dari uji statistik Chi-Square pada tingkat kemaknaan $\alpha=0,05$ diperoleh nilai $p$ value $=0,000$ yang berarti ada hubungan pengetahuan ibu dengan ketepatan waktu pemberian imunisasi BCG sehingga hipotesis yang menyatakan bahwa ada hubungan pengetahuan ibu dengan ketepatan waktu pemberian Imunisasi BCG pada bayi terbukti secara statistik.

Hasil Odds Ratio diperoleh nilai 16,958 yang berarti bahwa responden yang pengetahuannya baik berpeluang 16,958 kali lebih besar ketepatan waktunya dalam memberikan imunisasi BCG pada bayinya dibandingkan dengan responden yang pengetahuannya kurang baik.

\section{PEMBAHASAN}

Pembahasan hasil penelitian ini menguraikan tentang hasil penelitian dengan konsep terkait dan hasil penelitian terdahulu. Hasil penelitian ini secara umum sudah menjawab pertanyaan sesuai dengan tujuan penelitian yaitu untuk mengetahui hubungan pendidikan, pekerjaan, sikap dan pengetahuan dengan ketepatan pemberian imunisasi BCG pada bayi di wilayah kerja Puskesmas Taman Bacaan Kota Palembang Tahun 2021, setelah dilakukan uji statistik bivariat diperoleh sebagai berikut:

\section{Pendidikan}

Berdasarkan hasil univariat diketahui bahwa dari 87 responden yang pendidikannya rendah sebanyak 50 responden $(57,5 \%)$ lebih besar dari responden yang pendidikannya tinggi yaitu sebanyak 37 responden (42,5\%).

Hasil bivariat diketahui bahwa dari 50 responden yang pendidikannya rendah ada 37 responden $(74,0 \%)$ yang tidak tepat waktu dalam memberikan imunisasi BCG pada bayinya dan 13 responden $(26,0 \%)$ yang tepat dalam memberikan imunisasi BCG pada bayinya sedangkan dari 37 responden yang pendidikannya tinggi ada 9 responden $(18,9 \%)$ yang tidak tepat waktu dalam memberikan imunisasi BCG pada bayinya dan tepat waktu memberikan imunisasi BCG pada bayinya yaitu sebanyak 28 responden $(75,7 \%)$.

Dari uji statistik Chi-Square pada tingkat kemaknaan $\quad=0,05$ diperoleh nilai $\mathrm{p}$ value $=0,000$ yang berarti ada hubungan Pendidikan ibu dengan ketepatan waktu pemberian imunisasi BCG sehingga hipotesis yang menyatakan bahwa ada hubungan pendidikan dengan ketepatan waktu 


\section{Jurnal Kebidanan : Jurnal Medical Science Ilmu Kesehatan Akademi Kebidanan Budi Mulia Palembang Volume.11 No.2, Desember 2021 \\ Available online https://journal.budimulia.ac.id/}

pemberian imunisasi BCG terbukti secara statistik. Hasil Odds Ratio diperoleh nilai 8,855 yang berarti bahwa responden yang pendidikannya tinggi berpeluang $8,855 \mathrm{kali}$ lebih besar ketepatan waktunya memberikan imunisasi BCG pada bayinya dibandingkan dengan responden yang berpendidikan rendah.

Pengukuran Pendidikan menurut Notoatmodjo tingkat atau jenjang pendidikan terdiri atas pendidikan tinggi (tamat/tidak tamat perguruan tinggi dan tamat SMA/sederajat), rendah (tidak sekolah, tamat/tidak tamat SD, tamat /tidak tamat SMA sederajat).

Menurut Triana Vivi (2018), Latar belakang pendidikan orang tua baik kepala keluarga ataupun istri merupakan salah satu unsur penting dalam mewariskan setatus kesehatan bagi anak-anak mereka. Hubungan positif antara tingkat pendidikan orang tua dengan kesehatan anak telah banyak diungkapkan para ahli. Dalam hal ini pendidikan ibu sangat mempengaruhi kesehatan dan kekebatan anak. Pada ibu yang pendidikannya tinggi, maka ibu mengetahui tentang manfaat imunisasi dasar pada anak dan ibu mau membawa anaknya ke Posyandu untuk mendapatkan imunisasi dasar.

Sedangkan menurut Azizah (2016), Tingkat pendidikan orangtua akan mempengaruhi pengetahuan yang dimilikinya. Perbedaan tingkat pendidikan akan mempengaruhi perbedaan dalam memberikan tanggapan dan pemahaman terhadap penerimaan pesan yang disampaikan. Semakin tinggi tingkat pendidikan ibu, maka akan semakin mudah dalam menerima inovasi-inovasi baru yang dihadapannya termasuk imunisasi. Tingkat pendidikan dan pengetahuan ibu sangat mempengaruhi terlaksananya kegiatan pelaksanaan imunisasi anak/bayi, baik pedidikan formal maupun non formal.

Berdasarkan penelitian Albertina, dkk (2019) tentang faktor-faktor yang berhubungan dengan Ketepatan waktu pemberian imunisasi BCG. Hasil penelitian menunjukan bahwa faktor yang berhubungan bermakna dengan ketepatan waktu dini pemberian imunisasi yaitu pendidikan $(\mathrm{p}=0,001)$, pengetahuan $(\mathrm{p}=0,043)$, sikap $(\mathrm{p}=0,032)$, dan pekerjaan $(\mathrm{p}=0,012)$.

Hasil penelitian Yuliana Makamban (2014) dengan judul faktor yang berhubungan dengan cakupan imunisasi dasar lengkap pada bayi. Hasil penelitian menunjukkan sebagian besar ibu berpendidikan rendah sebanyak 12 orang (40,9\%), ibu yang pendidikannya tinggi 28 orang $(59,1 \%)$ dan ibu yang tepat waktu dalam pemberian imunisasi BCG yaitu sebanyak 25 orang $(58,1 \%)$. Adanya hubungan secara signifikan antara pendidikan dengan ketepatan waktu pemberian imunisasi $\mathrm{BCG}$ dengan $\mathrm{p}$-value $0,004<\alpha(0,05)$.

Berdasarkan hasil penelitian Rachmawati (2017) tentang Faktor-faktor yang Mempengaruhi Kepatuhan Ibu dalam Pemberian Imunisasi Dasar pada Balita di Dukuh Pilangbangau Desa Sepat Masaran Sragen Tahun 2017 sebagian besar ibu berpendidikan SD, SMP, maupun SMA lebih cenderung untuk tidak patuh dalam pemberian imunisasi dasar pada balitanya, sedangkan ibu yang berpendidikan akademik/ sarjana sebagian besar patuh dalam pemberian imunisasi dasar pada balitanya.

Dari hasil penelitian, teori dan penelitian terkait peneliti berasumsi bahwa pendidikan ibu yang tinggi lebih besar pengaruhnya dalam ketepatan waktu pemberian imunisasi BCG pada bayinya dibandingkan dengan pendidikan ibu yang rendah hal ini dikarenakan semakin tinggi tingkat pendidikan ibu, maka akan semakin mudah dalam menerima inovasi-inovasi baru yang dihadapannya termasuk imunisasi.

\section{Pekerjaan}

Hasil analisis univariat diketahui bahwa dari 87 responden yang tidak bekerja sebanyak 56 responden $(64,4 \%)$ lebih besar dari responden yang bekerja yaitu sebanyak 31 responden $(35,6 \%)$.

Hasil bivariat diketahui bahwa dari 56 responden yang tidak bekerja ada 20 responden $(35,7 \%)$ yang tidak tepat waktu dalam memberikan imunisasi BCG pada 
bayinya dan 36 responden $(64,3 \%)$ yang tepat dalam memberikan imunisasi BCG pada bayinya sedangkan dari 31 responden yang bekerja ada 26 responden $(83,9 \%)$ yang tidak tepat waktu dalam memberikan imunisasi BCG pada bayinya dan tepat waktu memberikan imunisasi BCG pada bayinya yaitu sebanyak 5 responden (16,1\%).

Dari uji statistik Chi-Square pada tingkat kemaknaan $\alpha=0,05$ diperoleh nilai $p$ value $=0,000$ yang berarti ada hubungan Pekerjaan ibu dengan ketepatan waktu pemberian imunisasi BCG sehingga hipotesis yang menyatakan bahwa ada hubungan pekerjaan dengan ketepatan waktu pemberian imunisasi BCG terbukti secara statistik. Hasil Odds Ratio diperoleh nilai 0.107 yang berarti bahwa responden yang bekerja berpeluang 0,107 kali lebih besar ketepatan waktunya memberikan imunisasi BCG pada bayinya dibandingkan dengan responden yang tidak bekerja.

Menurut Kurniati di Surakarta Tahun 2018 bahwa ibu rumah tangga lebih banyak mempunyai waktu dirumah sehingga lebih dapat memperhatikan pemberian imunisasi pada anaknya. Status pekerjaan seorang ibu dapat berpengaruh terhadap kesempatan dan waktu yang digunakan untuk meningkatkan pengetahuan dengan cara menambah pengetahuan tentang imunisasi dan perhatian terhadap kesehatan anak-anaknya.

Menurut Makamban et al (2014) ibu yang bekerja harus terbagi perhatiannya pada pekerjaan dan mengurus anak yang mengakibatkan pemberian imunisasi dasar lengkap tidak menjadi prioritas sedangkan ibu yang tidak bekerja atau ibu rumah tangga lebih patuh dalam pemberian imunisasi dasar lengkap. Ibu yang tidak bekerja atau ibu rumah tangga mempunyai waktu lebih banyak di rumah sehingga perhatian terhadap kesehatan anak yang dalam hal ini adalah pemberian imunisasi dasar lengkap menjadi lebih baik apabila dibandingan dengan ibu yang bekerja

Penelitian yang dilakukan oleh Yuliana Makamban (2014) tentang "Faktor yang berhubungan dengan cakupan imunisasi dasar lengkap pada bayi" menunjukkan ada hubungan antara pekerjaan dengan status imunisasi dasar pada bayi. Sebagian besar responden bekerja sebagai ibu rumah tangga, karena itu ibu mempunyai banyak waktu untuk mengimunisasi anaknya, tidak terburuburu pulang karena alasan bekerja. Ibu yang bekerja sebagai guru atau dosen tetapi digantikan oleh orangtua untuk mengimunisasi anaknya, namun tetap saja ada ibu yang tidak mengimunisasi anaknya dengan alasan bekerja. Ibu yang bekerja maupun yang tidak bekerja mempunyai kesempatan yang sama untuk memperoleh informasi tentang imunisasi dasar baik dari petugas kesehatan maupun berbagai media seperti TV, radio dan surat kabar.

Berdasarkan penelitian Albertina, dkk (2019) tentang faktor-faktor yang berhubungan dengan Ketepatan waktu pemberian imunisasi BCG. Hasil penelitian menunjukan bahwa faktor yang berhubungan bermakna dengan ketepatan waktu dini pemberian imunisasi yaitu pendidikan $(p=0,001)$, pengetahuan $(p=0,043)$, sikap $(\mathrm{p}=0,032)$, dan pekerjaan $(\mathrm{p}=0,012)$.

Berdasarkan hasil penelitian Rachmawati (2017) tentang Faktor-faktor yang Mempengaruhi Kepatuhan Ibu dalam Pemberian Imunisasi Dasar pada Balita di Dukuh Pilangbangau Desa Sepat Masaran Sragen Tahun 2017 sebagian besar ibu berpendidikan SD, SMP, maupun SMA lebih cenderung untuk tidak patuh dalam pemberian imunisasi dasar pada balitanya, sedangkan ibu yang berpendidikan akademik/ sarjana sebagian besar patuh dalam pemberian imunisasi dasar pada balitanya.

Dari hasil penelitian, teori dan penelitian terkait peneliti berasumsi bahwa pekerjaan ibu berhubungan dengan ketepatan waktu pemberian imunisasi BCG. Ibu yang tidak bekerja lebih banyak memiliki waktu untuk membawa anaknya ke Posyandu untuk memberikan imunisasi secara lengkap kepada bayinya dibandingkan dengan ibu yang bekerja hal ini dikarenakan Ibu yang bekerja diluar rumah atau karena tuntutan pekerjan 
membuat ibu lupa untuk memberikan imunisasi pada anaknya sesuai dengan jadwal.

\section{Sikap}

Hasil analisis univariat diketahui bahwa dari 87 responden yang tidak sebanyak 46 responden $(52,9 \%)$ lebih besar dari responden yang bekerja yaitu sebanyak 41 responden $(47,1 \%)$.

Hasil bivariat diketahui bahwa dari 46 responden yang tidak mendukung ada 37 responden $(80,4 \%)$ yang tidak tepat waktu dalam memberikan imunisasi BCG pada bayinya dan 9 responden $(19,6 \%)$ yang tepat dalam memberikan imunisasi BCG pada bayinya sedangkan dari 41 responden yang mendukung ada 9 responden $(22,0 \%)$ yang tidak tepat waktu dalam memberikan imunisasi BCG pada bayinya dan tepat waktu memberikan imunisasi BCG pada bayinya yaitu sebanyak 32 responden $(78,0 \%)$.

Dari uji statistik Chi-Square pada tingkat kemaknaan $\alpha=0,05$ diperoleh nilai $p$ value $=0,000$ yang berarti ada hubungan sikap ibu dengan ketepatan waktu pemberian imunisasi BCG sehingga hipotesis yang menyatakan bahwa ada hubungan pekerjaan dengan ketepatan waktu pemberian imunisasi BCG terbukti secara statistik. Hasil Odds Ratio diperoleh nilai 43,313 yang berarti bahwa responden yang mendukung berpeluang 43,3 kali lebih besar ketepatan waktunya memberikan imunisasi BCG pada bayinya dibandingkan dengan responden yang tidak mendukung.

Menurut Notoadmojo (2012), Sikap yang ada pada seseorang akan memberikan warna atau corak pada perilaku atau perbuatan orang yang bersangkutan. Dengan mengetahui sikap seseorang dapat menduga bagaimana respons atau perilaku yang akan diambil oleh orang yang bersangkutan, terhadap sesuatu masalah atau keadaan yang dihadapkan kepadanya. Jadi dengan mengetahui sikap seseorang, orang akan mendapatkan gambaran kemungkinan perilaku yang timbul dari orang yang bersangkutan.
Sedangkan menurut Hoffmans (2013) sikap merupakan reaksi internal seseorang yang dipengaruhi oleh berbagai faktor, yaitu pengalaman pribadi, kebudayaan, orang lain yang dianggap penting, agama, serta faktor emosi dalam diri individu yang mempunyai peranan penting dalam terbentuknya sikap. Sikap tidak dibawa sejak lahir, tetapi dipelajari dan dibentuk berdasarkan pengalaman individu sepanjang perkembangan selama hidupnya.

Berdasarkan hasil penelitian yang dilakukan Marfiani (2016) dengan judul hubungan tingkat pengetahuan dan sikap ibu dengan ketepatan pemberian imunisasi dasar di wilayah kerja Puskesmas Jati Negara Kendari yang menunjukkan bahwa ada hubungan yang signifikan antara sikap ibu dengan ketepatan pemberian imunisasi dasar pada bayi usia 11 bulan ( $\mathrm{p}$ value $=0,001$ ) Sedangkan penelitian Albertina, dkk (2019) tentang faktor-faktor yang berhubungan dengan Ketepatan waktu pemberian imunisasi BCG. Hasil penelitian menunjukan bahwa faktor yang berhubungan bermakna dengan ketepatan waktu dini pemberian imunisasi yaitu pendidikan $(\mathrm{p}=0,001)$, pengetahuan $(\mathrm{p}=0,043)$, sikap $(\mathrm{p}=0,032)$, dan pekerjaan $(\mathrm{p}=0,012)$.

Penelitian menurut Yulinda (2018) menunjukkan bahwa sikap mayoritas bersikap positif yaitu sebanyak 60 responden $(71,4 \%)$ menyatakan bahwa ada hubungan Sikap Orang Tua dengan Pemberian Imunisasi BCG pada Bayi Usia 0-3 Bulan di Wilayah Kerja Puskesmas Bireum Bayeun Kecamatan Bireum Bayeun Kabupaten Aceh Timur Tahun 2018.

Dari hasil penelitian, teori dan penelitian terkait peneliti berasumsi bahwa sikap ibu berhubungan dengan ketepatan waktu pemberian imunisasi BCG yang diberikan pada bayinya. Sikap ibu yang positif lebih besar daripada sikap ibu yang negatif dalam hal ketepatan waktu pemberian imunisasi BCG hal ini dikarenakan dalam berpikir sikap ibu yang positif berniat untuk mengimunisasikan anaknya untuk mencegah supaya anaknya tidak terkena penyakit yang 
dapat dicegah dengan imunisasi. Sedangkan ibu yang berpikir negatif, mereka tidak bersedia untuk membawa imunisasi bayinya disebabkan karena belum memahami secara benar dan mendalam mengenai imunisasi dasar, kurang memperhatikan jadwal imunisasi dan kesadaran yang kurang mengenai pemberian imunisasi.

\section{Pengetahuan}

Hasil analisis univariat diketahui bahwa dari 87 responden yang tidak sebanyak 45 responden $(51,7 \%)$ lebih besar dari responden yang bekerja yaitu sebanyak 42 responden $(48,3 \%)$.

Hasil bivariat diketahui bahwa dari 45 responden yang pengetahuannya kurang baik ada 37 responden $(82,2 \%)$ yang tidak tepat waktu dalam memberikan imunisasi BCG pada bayinya dan 8 responden $(17,8 \%)$ yang tepat dalam memberikan imunisasi BCG pada bayinya sedangkan dari 42 responden yang pengetahuannya baik ada 9 responden $(21,4 \%)$ yang tidak tepat waktu dalam memberikan imunisasi BCG pada bayinya dan tepat waktu memberikan imunisasi BCG pada bayinya yaitu sebanyak 33 responden $(78,6 \%)$.

Dari uji statistik Chi-Square pada tingkat kemaknaan $\alpha=0,05$ diperoleh nilai $p$ value $=0,000$ yang berarti ada hubungan pengetahuan ibu dengan ketepatan waktu pemberian imunisasi BCG sehingga hipotesis yang menyatakan bahwa ada hubungan pengetahuan ibu dengan ketepatan waktu pemberian imunisasi BCG terbukti secara statistik. Hasil Odds Ratio diperoleh nilai 16,958 yang berarti bahwa responden yang mendukung berpeluang 16,958 kali lebih besar ketepatan waktunya memberikan imunisasi BCG pada bayinya dibandingkan dengan responden yang pengetahuannya kurang baik.

$$
\text { Menurut Notoadmojo }
$$

Pengetahuan adalah hasil tahu yang berasal dari proses penginderaan manusia terhadap suatu obyek dan pengetahuan seseorang biasanya diperoleh dari pengalaman yang berasal dari berbagai mcam sumber misalnya media massa, media elektronik, buku petunjuk, petugas kesehatan, media postes, kerabat dekat, dan sebagainya. Pengetahuan atau kognitif merupakan domain yang sangat penting untuk terbentuknya tindakan seseorang (overt behavior).

Menurut Gustin, pengetahuan ibu dapat diperoleh dari pendidikan, pengamatan ataupun informasi yang didapatkan seseorang. Dengan adanya pengetahuan, seseorang dapat melakukan perubahan-perubahan sehingga tingkah laku dari seseorang dapat berkembang. Menurut Ismet salah satu faktor yang mempengaruhi kepatuhan pemberian imunisasi adalah tingkat pengetahuan, semakin tinggi pengetahuan seseorang tentang imunisasi, memungkinkan orang tersebut untuk mengaplikasikan pengetahuannya yaitu dalam hal ini memberikan imunisasi kepada anak secara lengkap atau tepat. Bila penerimaan perilaku baru didasari oleh pengetahuan.

Pengukuran Pengetahuan dapat dilakukan dengan wawancara atau angket yang menanyakan tentang isi materi yang ingin diukur dari subyek penelitian atau responden. Berdasarkan hasil penelitian yang dilakukan Marfiani (2016) dengan judul hubungan tingkat pengetahuan dan sikap ibu dengan ketepatan pemberian imunisasi dasar di wilayah kerja Puskesmas Jati Negara Kendari yang menunjukkan bahwa ada hubungan yang signifikan antara pengetahuan ibu dengan ketepatan pemberian imunisasi dasar pada bayi usia 11 bulan. Hasil uji statistik variabel pengetahuan menunjukkan terdapat hubungan yang bermakna antara pengetahuan ibu tentang imunisasi dengan ketepatan pemberian imunisasi $(p$ value $=0,000)$.

Hal ini sesuai dengan beberapa penelitian lainnya sebagai contoh penelitian yang telah dilakukan oleh Senewe di Puskesmas Tongkaina Kecamatan Bunaken Kota Madya Manado tahun $2017(\mathrm{p}=0,012)$ penelitian yang dilakukan oleh Riyanto di Kota Serang Tahun 2013 ( $\mathrm{p}=0,000)$. Dalam penelitian ini, didapatkan hasil ibu yang memiliki pengetahuan yang baik mengenai 
imunisasi mempunyai ketepatan pemberian imunisasi tertinggi, yaitu sebesar 78,2\%. Dimana dalam analisis bivariat ibu yang memiliki pengetahuan tinggi diketahui bahwa proporsi anak yang memperoleh imunisasi lengkap lebih besar.

Penelitian menurut Yulinda (2018) menunjukkan bahwa sikap mayoritas mayoritas berpengetahuan kurang yaitu sebanyak 39 responden $(46,4 \%)$, menyatakan bahwa ada hubungan Pengetahuan ibu dengan Pemberian Imunisasi BCG pada Bayi Usia 0-3 Bulan di Wilayah Kerja Puskesmas Bireum Bayeun Kecamatan Bireum Bayeun Kabupaten Aceh Timur Tahun 2018.

Dari hasil penelitian, teori dan penelitian terkait peneliti berasumsi bahwa pengetahuan $\mathrm{ibu}$ berhubungan dengan ketepatan waktu pemberian imunisasi BCG. Ibu yang berpengetahuan baik lebih banyak dalam ketepatan waktu pemberian imunisasi BCG pada bayinya daripada ibu yang berpengetahuan kurang baik hal ini dikarenakan Ibu yang berpengetahuan baik akan lebih mudah untuk mengerti tentang apa saja yang berkaitan dengan imunisasi sehingga ibu akan patuh dalam membawa anak untuk diimunisasi.

\section{KESIMPULAN}

Berdasarkan penelitian yang dilakukan, diperoleh dari hasil penelitian telah sesuai dengan tujuan khusus yaitu mengetahui hubungan Pendidikan, pekerjaan, sikap dan pengetahuan dengan ketepatan waktu pemberian imunisasi BCG pada bayi di wilayah kerja Puskesmas Taman Bacaan kota Palembang tahun 2021. Berdasarkan hubungan dari masing-masing variabel yang diteliti, maka penulis mengambil kesimpulan bahwa pendidikan, pekerjaan, sikap dan pengetahuan memiliki hubungan yang bermakna dengan ketepatan waktu pemberian imunisasi BCG pada bayi.

\section{DAFTAR PUSTAKA}

\author{
Arifin. Hubungan Tingkat Pengetahuan Ibu \\ Tentang Pentingnya Imunisasi Dasar
}

\begin{abstract}
dengan Kepatuhan Melaksanakan Imunisasi di BPS Hj. Umi Salamah di desa Kauman, Peterongan, Jombang, tahun 2011. Prosiding Sminas Competitive Advantage, Vol 1, No. 2. 2018
\end{abstract}

Astinah.Faktor-Faktor Yang Mempengaruhi Kepatuhan Ibu Pada Pemberian Imunisasi Dasar Di Posyandu Teratai Di Wilayah Kerja Puskesmas Tamamaung Makasar. E-library STIKES Nani Hasanuddin Makasar Vol. 2, No. 6. 2017.

Ayubi, Dian. Kontribusi Pengetahuan Ibu terhadap Status Imunisasi Anak di Tujuh Provinsi di Indonesia. Jurnal Kesehatan Wiraraja Medika. 2017.

Azwar,S.2018. Sikap Manusia Teori dan Pengukurannya. Jakarta : Pustaka Pelajar Offset

Dinas Kesehatan Provinsi Sumatera Selatan, 2019, Profil Dinas Kesehatan Provinsi Sumatera Selatan

Depkes RI. 2018. Informasi Dasar Imunisasi Rutin Serta Kesehatan Ibu dan Anak bagi Kader, Petugas Lapangan dan Organisasi Kemasyarakatan. Jakarta: Depkes RI

Depkes RI. 2018. Profil Kesehatan Indonesia 2017. Jakarta : Kementrian Kesehatan RI

Dyah, Annisa. 2013. Hubungan pengetahuan dan sikap ibu dengan ketepatan imunisasi polio di posyandu Rw 10 Kampung Banteng Kota Semarang. Skripsi. Fakultas Kesehatan Masyarakat UNIMUS. Semarang

Fitriani, Eka. Faktor yang mempengaruhi ketepatan pemberian Imunisasi Dasar di wilayah kerja Puskesmas Perawatan Tanjung Seloka Kabupaten Kotabaru tahun 2017, Jurnal Kesehatan Politeknik 
Kesehatan Kementerian Kesehatan Yogyakarta 2017

Harmasdiani, Riska. Pengaruh Karakteristik ibu terhadap ketidakpatuhan pemberian imunisasi dasar lengkap pada anak bawah dua tahun. Jurnal epidemiologi vol 3 no 3 sept 2015.

Hindriyawati, W; Rosalina; Wahyuni. Hubungan Tingkat Pengetahuan Ibu Tentang Imunisasi Dengan Kepatuhan Ibu Dalam Pemberian Imunisasi Dasar Pada Bayi Di Puskesmas Cawas. Jurnal Kebidanan Arimbi, Vol V No. 4. 2012.

Kemenkes RI. 2017. Data dan Informasi Profil Kesehatan Indonesia Tahun 2016.

Kemenkes RI. 2014. Buku Ajar Imunisasi, Hari AIDS Sedunia 2014.

Kemenkes RI (2018). Laporan Nasional Riskesdas 2018. Jakarta: Kemenkes RI, 154-66.

Makamban, Yuliana. 2014. Faktor yang berhubungan dengan cakupan imunisasi dasar lengkap pada bayi di wilayah kerja Puskesmas Antara Kota Makassar. UNHAS. Makasar

Notoatmodjo. Pengetahuan dan Sikap. Jakarta : Rineka Cipta. 2007.

Notoatmodjo, Soekidjo. 2010. Metode Peneltian Kesehatan. Jakarta : PT Rineka Cipta

Notoatmodjo, Soekidjo. 2011. Pendidikan dan Perilaku Kesehatan. Jakarta : PT Rineka Cipta

Notoatmodjo, Soekidjo. 2014. Ilmu Perilaku Kesehatan. Jakarta : PT Rineka Cipta
Nursalam. 2011. Konsep dan Penerapan Metodologi Penelitian Ilmu Keperawatan. Jakarta: Salemba Medika.

PERMENKES. 2017. Peraturan Menteri Kesehatan Republik Indonesia No.12 Tahun 2017 tentang Penyelenggaraan Imunisasi.

Profil Puskesmas Taman Bacaan, 2019, Data Dasar Puskesmas Taman Bacaan

Rahmawati. Faktor-faktor yang mempengaruhi Kelengkapan Imunisasi Dasar di Kelurahan Krembangan Utara Kota Surabaya sebagai Upaya Pencegahan Penyakit. Skripsi. Fakultas Kesehatan Masyarakat Universitas Airlangga. 2013.

Ranuh, I.G.N.Gde, dkk. 2014. Pedoman Imunisasi Di Indonesia Edisi 5. Jakarta : IDAI

Riyanto, Dwi Agung. Hubungan Pengetahuan dan Sikap Ibu tentang Imunisasi Dasar dengan Perilaku Pelaksanaan Imunisasi Dasar pada Balita di Kampung Cantilan Kelurahan Kagungan Kecamatan Kasemen Kota Serang Tahun 2013.

Suparyanto. 2011. Tumbuh Kembang dan Imunisasi. Jakarta : EGC

Triana, Vivi. Faktor yang Berhubungan dengan Pemberian Imunisasi Dasar Lengkap pada BAyi Tahun 2015. Vol.10, No 2 (2016). 